\title{
Research and theory of Corporate Political Activity (CPA): a bibliometric analysis
}

\author{
Raul Beal Partyka', Jeferson Lana², Marina Amado Bahia Gama³, Rosilene \\ Marcon 4 \\ ${ }^{1}$ Universidade do Vale do Itajaí - raul@edu.univali.br \\ 2 Universidade do Vale do Itajaí - jlana@univali.br \\ 3 Fundação Getúlio Vargas EAESP - abgama@gmail.com \\ 4 Universidade do Vale do Itajaí - rmarcon@univali.br
}

\section{KEYWORDS}

Corporate Political Activity.

Corporate Political Action;

CPA;

Nonmarket Strategy;

Bibliometric.

Received 16.12.2018

Reviewed 20.03.2019

Accepted 25.03.2019

ISSN 1980-4431

Double blind review

\section{ABSTRACT}

Corporate Political Activity (CPA) are ways in which companies use themselves to try to influence regulatory policies and environments in their interests. This article aims to highlight the importance of the CPA in the context of companies seeking political alignment to develop their strategies. Through a bibliometric analysis, based on 180 articles, it was possible to verify that the United States, Canada, and China have effectively advanced research on the subject. Due to the need to develop further studies on the subject in Brazil, suggestions for future research are presented, because it is understood that, through a greater number of studies related to CPAs, we will understand the reasons and forms by which companies are involved with the regulatory environment. The article contributes to clarify the field of corporate political activities, their classification, and implications, advancing with future needs for the researchers of this community.

\section{PALAVRAS-CHAVE}

Atividade Política Corporativa; Ação Política Corporativa; CPA;

Estratégia de não mercado; Bibliométrica.

\section{RESUMO}

As atividades políticas corporativas (CPA, do inglês Corporate Political Activity) são formas pelas quais as empresas se utilizam para tentar influenciar as políticas e os ambientes regulatórios em favor de seus interesses. Este artigo tem como objetivo destacar a importância da CPA no contexto de as empresas buscarem alinhamento político para desenvolverem suas estratégias. Por meio de uma análise bibliométrica, realizada com base em 180 artigos, foi possível verificar que Estados Unidos, Canadá, China têm avançado efetivamente em pesquisas a respeito do tema. Pela necessidade de desenvolver mais estudos sobre o assunto no Brasil, sugestões de futuras pesquisas são apresentadas, pois se entende que, por meio de um maior número de estudos relacionados às CPAs, passa-se a compreender os motivos e formas pelas quais empresas se envolvem com o ambiente regulatório. $\mathrm{O}$ artigo contribui em clarear o campo das atividades políticas corporativas, sua classificação e implicações, avançando com as necessidades futuras para os pesquisadores desta comunidade. 


\section{Introduction}

The companies opt for political connections in order to influence the public power, and usually, their channel of action (Dorobantu et al., 2017) are the donations to the political campaigns. Therefore, they seek to finance political projects that are more interesting and with which they are more aligned. This direct involvement in politics occurs when companies realize that their particular interests in the business vs. state relationship are threatened by specific policy deliberations (Suarez, 2000).

Corporations also put pressure on policymakers (Buchholz, 1988; Mack, 1997), in order to communicate their views to legislators on proposed legislation. These activities give firms the opportunity to provide legislators with the motives for adopting a specific position on proposed legislation and attempting to influence policy outcomes (Hillman \& Hitt, 1999; Mack, 1997).

In this sense, this research seeks to make a survey of existing publications on corporate political activity (CPA). The objective is to understand the ability of organizations to gain access to the regulatory environment and how this can influence the legislative process in a more business-friendly way and/or broaden access to government contracts.

Often organizations can spend a tremendous amount of resources trying to achieve even the smaller goals by not having access to insiders in the political process that can explain the functioning of the rules and the dynamics of political processes. In turn, the costs and asymmetry of information can affect operating costs and, potentially, the company's performance (Hillman et al., 1999).

Thus, through a literature review related to CPAs, it was intended to show that the actual expenditure of a company in relation to the formulation of public policies depends on the participation of the company in the political process, as well as on its ability to persuade policymakers to take positions that favor it. That is, this article aimed to clarify the field of corporate political activities, their classification, and implications, advancing with future needs for researchers and, above all, presenting the contribution of Brazilian research.

Thus, this paper shows the main publications and results of CPA research in the world and in Brazil and how this field of study can be expanded, since "the ability to influence a political decision in a company-friendly way is closely intertwined with the improvement of business performance" (Hillman et al., 2004, p. 847)

In this research, a sample of 180 articles was used. The results show that publications on CPA began to have significant numbers from the year 2011, reaching the apex in 2016. The top ten authors on the subject represent more than $30 \%$ of the total sample captured. In addition, $79 \%$ of the articles are empirical. It was also noticed that the empirical studies increased vertiginously and the theoretical articles did not have a great expression of publications throughout the analyzed period.

The methodology of the captured studies was also classified. In this sense, more than $50 \%$ of the sample is represented by quantitative articles, and the second classification, theoretical test, represents only slightly more than $16 \%$.

The theories used by the authors were also categorized, and the CPA theory itself appeared in half of the articles in the sample. On the other hand, the other theories found are proportionally distributed among the other studies. The lobbying activity is the most used by the authors as a study variable, in empirical articles and also in theoretical articles.

Finally, a predominance of studies developed in the United States of America (USA) was observed. Besides the US, China and Canada also have more advanced research on the subject. Thus, the question that arises is: why are there few studies on the subject in Brazil? In studies already done in the country, we note the importance of CPA in companies, their use in corporate strategies.

In this study, the research questions and the discoveries of the 30 most cited articles are also reported. In the following section, the theoretical reference for to the research is approached. Section 3 is devoted to a more detailed presentation of methods and discoveries.

Data analysis and discussion of results are presented in section 4. In addition, successful avenues of CPA studies and a listing of new findings provided by this study.

In section 5 one does research in the national context. Section 6 concludes by commenting on the limitations and presenting the suggestions for future research, obtained on the basis of the investigations and identified in the study implications.

\section{Theoretical Framework}

Revista de Negócios, v. 24, n. 1, p. 7-20, January, 2019. 
Corporate political activity (CPA) is a subfield of the nonmarket strategy, which studies the political actions of companies in the regulatory environment (Boddewyn, 2007; Getz, 1997). CPA is defined as "corporate attempts to shape government policy" (Hillman et al., 2004, p. 837)

It is important to differentiate the CPA from works that deal with corruption since the CPA does not investigate corruption and does not promote activities against the law. The interest is in the actions that companies take in the formal rules of the game and that even some authors value (Porter \& Kramer, 2006).

Corporate political engagements can be characterized as (a) corporate political actions and (b) corporate political activities, and have a corresponding sense. While the first term refers to "any deliberate firm action intended to influence government policy or process" (Getz, 1997, p. 32), the second, corporate political actions, refers literally to actions conditioned by institutional characteristics of political environments and structured by the organization to make strategic decisions within companies (Windsor, 2007).

The two terms are closely linked, since they relate to activities and actions in the literal sense of the word, before the corporate political environment. In this sense, we can mention the Political Action Committees (PACs) in the United States, which are entities created to receive campaign contributions. Political action has allowed companies to achieve goals such as entering new markets, ensuring the viability of current markets, reaffirming the autonomy of planning, establishing competitive market barriers and protecting current markets (Gundlach et al., 1992).

Creating and preserving the competitive advantage of today's markets is a challenge to all strategic managers. The Corporate political activity emerged as a remarkable research framework to explain the company's performance in political arenas as a way to create and sustain the advantage (Hillman et al., 2004).

Finally, the CPA allows behavior that is not necessarily linked to a commercial strategy. It concentrates only on the behavior carried out in the governmental arena. There is a consideration of a substantial portion of the academic work in business and its environment and in the relations between business and government (Getz, 1997).

\section{Method}

Motivated by previous readings, it was found in the literature review as the screening of documents on a topic, with information, ideas, data and written evidence from a particular point of view to achieve certain objectives or express certain opinions, as well as the effective evaluation in relation to the research carried out (Hart, 1998). In this article, the bibliometric method followed the model of Botelho et al. (2011), in order to provide the synthesis and analysis of the scientific knowledge already produced on the subject investigated, in addition to providing information that would enable the readers to evaluate the pertinence of the procedures used in the elaboration of the review (Botelho et al., 2011).

This scientific procedure is intended to allow readers, researchers or not, to approach the problematic, since "bibliometric methods reveal great potential for the quantitative confirmation of categories derived subjectively in published reviews, as well as to explore the research landscape and identify the categories" (Zupic \& Cater, 2015, p. 457).

In this sense, a panorama about the scientific production was traced, with the objective of knowing the evolution of the theme over time and, above all, visualizing possible research opportunities related to corporate political activity (CPA) and corporate political action (CPA).

Therefore, this study sought to analyze the national and international scientific production on corporate political actions and corporate political activities. Throughout the study, such topics are treated only as CPA, which is justified by the corresponding meaning described in the previous section. To achieve the objective of this research, a bibliographic method was used in the Web of Science and Scopus databases. The period covered was from 1960 to 2017.

Some parameters were determined for the data collection. Firstly, the two bases were selected and the search terms were determined: "corporate political action" and "corporate political activity" and their plural variations. Another filter in this first moment was to determine that the terms should be present in the title or abstract. The preliminary result is presented in Table 1 , noting that studies of corporate political activities represent more than $80 \%$ of the initial research. 
Table 1. Terms found in the works

\begin{tabular}{|l|c|c|c|}
\hline & WOS & SCOPUS & TOTAL \\
\hline TERM & QTY. & QTY. & QTY. \\
\hline Activity/Activities & 148 & 156 & 304 \\
\hline Action/Actions & 37 & 36 & 73 \\
\hline TOTAL & $\mathbf{1 8 5}$ & $\mathbf{1 9 2}$ & $\mathbf{3 7 7}$ \\
\hline
\end{tabular}

Source: The authors (2019), based on primary data.

The records were then organized using Excel software. For this, a manual selection was made for the application of two filters: removal of duplicate articles and those not suitable for the theme. In addition to the articles duplicated between the two platforms, eight articles were excluded because they were of the type of revision of the same book; 17 articles on the topic Ethics; four from the Health area and two from Public Health; eight of Law; seven of Social; 24 of Public Policies, one on National Culture, and the last one removed for having referenced a CPA article only as a model of methodology.

Figure 1 shows the process of obtaining the sample, with the general characteristics of this review. Figure 1 allows other researchers to replicate the study, by presenting the research design.

Considering the query for the search terms, a total of 377 articles were captured and, after the filters were applied, the sample was delimited with a total of 180 selected papers.

Figure 1. Research design



Source: The authors (2019).

\section{Data Analysis and Discussion of Results}

This section aims to indicate the most relevant works that guided this research. The chapter is divided into sample data collection, data analysis and results. Several parameters are analyzed, such as classification of the studies over time, the methodology used, identification of theories, identification of activities/actions, the geographical distribution of the sample countries. Finally, we report the research questions and discoveries of the Top 30 most cited works.
First, Figure 2 shows the number of annual publications on the topic.

Figure 2. The behavior of CPA publications over time (number of publications per year)



Source: The authors (2019) based on primary data.

The first finding was from two pioneering publications in 1981: from Mulkern, Handler, and Godtfredsen, entitled Corporate PACs to fundraisers, and from Keim, Foundations of a political strategy for business. Although they are more than 30 years old, they are not among the most cited articles. Emphasis is given to the work since 1995, due to its higher incidence in citations. In this sense, the works of Getz (1997), Rehbein and Schuler (1999) and Hillman and Hitt (1999) stand out, specifically in this sample of articles selected. For authors such as Hillman et al. (2004) and Lawton et al. (2013), the focus on this theme started from the work of Shaffer (1995).

In the year 2006, there was a disruptive increase in the number of publications. In this CPA theme, 2006 recorded the highest incidence (four) since 1981, the year in which there were two publications. From the beginning until November 2017, the historical peak was in 2016, with 27 publications. This growth of interest over CPAs can be explained by Hillman e Hitt (1999) e Hillman et al. (2004), according to which corporate attempts to shape government policy in ways favorable to the company have not matched the prevalence of CPA practice in industry or political systems. The important progress of CPA understanding has been made and is derived from disciplines as comprehensive as strategic management, marketing, economics, sociology, finance, and political science.

When analyzing the composition of the 180 articles of this sample, it was verified that the term corporate political action(s) represents $17,22 \%$. Therefore, the highest incidence is with the term corporate political activity(ies), identified in 149

Revista de Negócios, v. 24, n. 1, p. 7-20, January, 2019. 
articles, according to Table 2 .

Table 2. Terms found in CPA works

\begin{tabular}{|l|c|c|}
\hline TERM & QTY. & \% \\
\hline Action/Actions & 31 & 17,22 \\
\hline Activity/Activities & 149 & 82,78 \\
\hline TOTAL & $\mathbf{1 8 0}$ & $\mathbf{1 0 0}$ \\
\hline
\end{tabular}

Source: The authors (2019) based on primary data.

Regarding the authors who publish the most about CPA, Table 3 records that Schuler, D. A., is the author who presents more publications, with ten articles.

Table 3. Top ten authors who most publish on CPA

\begin{tabular}{|c|l|c|c|}
\hline$\#$ & AUTHOR & QTY. & \% \\
\hline 1 & Schuler, D. A. & 10 & 5.56 \\
\hline 2 & Hadani, M. & 8 & 4.44 \\
\hline 3 & Rehbein, K. A. & 7 & 3.89 \\
\hline 4 & Barron, A. & 6 & 3.33 \\
\hline 5 & Rajwani, T. & 6 & 3.33 \\
\hline 6 & Brown, R. S. & 5 & 2.78 \\
\hline 7 & Lawton, T. & 5 & 2.78 \\
\hline 8 & Dahan, N. M. & 4 & 2.22 \\
\hline 9 & Hansen, W. L. & 3 & 1.67 \\
\hline 10 & $\begin{array}{l}\text { Jia, N. } \\
\text { Keim, G. D. }\end{array}$ & 3 & 1.67 \\
& $\begin{array}{l}\text { Lux, S. } \\
\text { Mitchell, N. J. } \\
\text { Tian, Z. } \\
\text { Werner, T. }\end{array}$ & & \\
\hline
\end{tabular}

Source: The authors (2019), based on primary data.

As indicated in Table 3, it was also identified the lack of some authors already recognized on issues that involve the corporate relationship with the political environment. This shows that these authors did not specifically use CPA findings during their research. Examples of this are Faccio, Gilmore, Saffar, and Boubakri.

Another point that deserves to be highlighted is the fact that the ten authors that produce the most published, together, 57 works, which corresponds to more than $31 \%$ of the total publications on CPAs.

Regarding the study classifications, it can be observed in Table 4 that the most used approach was the empirical one, with $79.4 \%$ of the studies found. A total of 143 articles used data collected in the field or secondarily, to elaborate the works on CPA.

Table 4. Classification of the study of CPA articles

\begin{tabular}{|l|c|c|}
\hline Type & QTY. & \% \\
\hline Empirical & 143 & 79,40 \\
\hline Theoretical & 37 & 20,60 \\
\hline TOTAL & 180 & 100 \\
\hline
\end{tabular}

Source: The authors (2019) based on primary data.
It was also sought to identify this classification over time, according to Figure 3, seeking to identify some standard activity of the researchers or moment of rupture in the searches.

Figure 3. The behavior of the study's classification over time

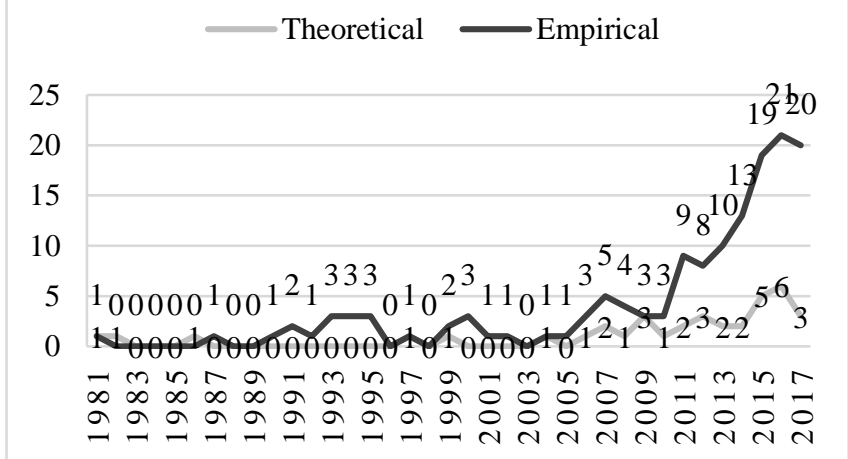

Source: The authors (2019) based on primary data.

As a result, we conclude that empirical-type studies were sovereign throughout the period, with the exception of two dates: 1982 and 1986, where there was a publication of the theoretical type in each period, against none of the empirical types. The same incidences were recorded in the years 1997 and 2004, with one paper for each classification, and 2009, with three for each classification. In Figure 3 it is still possible to visualize the periods in which both approaches had no publications. In addition, empirical research reached its apex in 2016, with 21 published articles.

The methodology used in the articles of the sample was also verified. Table 5 shows that there were six variations: quantitative, theoretical, literature review, case study, qualitative and qualiquanti (QQ), with the two methods in the same article, quantitative and qualitative. With more than $50 \%$ of the total sample, representing 94 articles, the methodology of the quantitative type was the most used among 180 articles. The theoretical essay appears, with only 29 articles.

Table 5. Methodology used

\begin{tabular}{|c|l|c|c|}
\hline$\#$ & \multicolumn{1}{|c|}{ TYPE } & QTY. & \% \\
\hline $\mathbf{1}$ & Quantitative & 94 & 52.22 \\
\hline $\mathbf{2}$ & Theoretical essay & 29 & 16.11 \\
\hline $\mathbf{3}$ & Literature review & 20 & 11.11 \\
\hline $\mathbf{4}$ & Case study & 20 & 11.11 \\
\hline $\mathbf{5}$ & Qualitative & 12 & 6.67 \\
\hline $\mathbf{6}$ & Quali-Quanti (QQ) & 5 & 2.78 \\
\hline & TOTAL & $\mathbf{1 8 0}$ & $\mathbf{1 0 0}$ \\
\hline
\end{tabular}

Source: The authors (2019) based on primary data. 
Table 6 also highlights the methods used in the articles, divided into qualitative and quantitative, as well as the technique used within each of the classifications.

In the quantitative method, multiple regression, OLS regression, ANOVA, MANOVA, multivariate analysis, and the t-test were the most important. The same scanning was done with the qualitative method, in which the content analysis was mainly identified.

Table 6. Methods used in sample articles

\begin{tabular}{|l|c|}
\hline \multicolumn{1}{|c|}{ QYPO } & QTY. \\
\hline \multicolumn{1}{|c|}{ QUALITATIVE } & $\mathbf{1 2}$ \\
\hline Content analysis & 3 \\
\hline Inductive study; meta-analysis; thematic analysis & 2 \\
\hline Systematic analysis; exploratory study; narrative & 1 \\
\hline \multicolumn{1}{|c|}{ QUATITATIVE } & $\mathbf{9 4}$ \\
\hline Regression & 48 \\
\hline Regression OLS & 15 \\
\hline ANOVA/MANOVA/ANCOVA & 6 \\
\hline Regression with panel data & 2 \\
\hline Regression logit; multiple regression; t-test & 1 \\
\hline $\begin{array}{l}\text { Sequence analysis; factorial exploratory analysis; chi- } \\
\text { square test; correlation; estimates of maximum } \\
\text { likelihood; MANCOVA; multilevel model for ordered } \\
\text { dependent variables; saturated model; GLS regression; } \\
\text { multilevel regression; multivariate regression; PLS } \\
\text { regression; linear structural relationships (LISREL); } \\
\text { theory of response by article (IRT); generalized } \\
\text { moments method (GMM) }\end{array}$ & \\
\hline $\begin{array}{l}\text { Source: The authors (2019), based on primary data. } \\
\text { Som }\end{array}$ & \\
\hline
\end{tabular}

Source: The authors (2019), based on primary data.

Table 7 lists the theoretical-type CPAs used by the authors to justify and demonstrate theories of corporate political actions and activities in their research.

Table 7. Identification in theoretical articles

\begin{tabular}{|l|c|c|}
\hline \multicolumn{1}{|c|}{ ACTIVITY/ACTION } & QTY. & $\%$ \\
\hline $\begin{array}{l}\text { Lobbying (spending or lobbying), } \\
\text { direct/indirect lobbying, reactive/proactive } \\
\text { lobbying. }\end{array}$ & 27 & 72.97 \\
\hline Contribution via PAC/existence of PAC & 11 & 29.73 \\
\hline $\begin{array}{l}\text { Contribution/Financing campaign or } \\
\text { candidate }\end{array}$ & 10 & 27.03 \\
\hline CPA/CPA transactional or relational & 9 & 24.32 \\
\hline Information & 4 & 10.81 \\
\hline $\begin{array}{l}\text { Activities/grassroots } \\
\text { involvement/mobilization }\end{array}$ & 4 & 10.81 \\
\hline Construction of Electoral Circles & 4 & 10.81 \\
\hline Coalition building/partnership & 3 & 8.11 \\
\hline $\begin{array}{l}\text { Advertising/support to public } \\
\text { causes/advocacies }\end{array}$ & 3 & 8.11 \\
\hline $\begin{array}{l}\text { Directors/Managers/Board connected, who } \\
\text { are politicians }\end{array}$ & 2 & 5.41 \\
\hline Political or economic education & 2 & 5.41 \\
\hline Financial Incentive or Disincentive & 2 & 5.41 \\
\hline $\begin{array}{l}\text { Strategy (information, money, taxation, and } \\
\text { votes) }\end{array}$ & 2 & 5.41 \\
\hline Government as a board member & 2 & 5.41 \\
\hline
\end{tabular}

\begin{tabular}{|c|c|c|}
\hline $\begin{array}{l}\text { Research reports and search results, } \\
\text { questions }\end{array}$ & 2 & 5.41 \\
\hline Litigation/threat of legal action & 2 & 5.41 \\
\hline Construction of internal/external voters & 2 & 5.41 \\
\hline $\begin{array}{l}\text { Level of participation (joint action in a } \\
\text { national industry association/national } \\
\text { employer's Federation/European industrial } \\
\text { association/European employers' } \\
\text { Federation) }\end{array}$ & 2 & 5.41 \\
\hline $\begin{array}{l}\text { Collective action; Voluntary agreements; } \\
\text { Collaboration between industry and policy } \\
\text { formulation; Political communication; } \\
\text { Hiring of experienced staff; CSR; } \\
\text { Develop/promote (new or existing) self- } \\
\text { regulation, alternative regulatory policy, } \\
\text { non-regulatory initiative; Donations; } \\
\text { Government Affairs Offices; Evidence- } \\
\text { based training; Provide current or future } \\
\text { employment; Provision of position papers; } \\
\text { Political expenses; Government investor; } \\
\text { Gifts, entertainment or other direct financial } \\
\text { incentive; Prevent the emergence, } \\
\text { neutralization/discredit potential } \\
\text { adversaries; Provision of information; } \\
\text { Political networks; Relations with NGOs; } \\
\text { Soft-money; Bribery; Replacement, } \\
\text { development, and implementation of } \\
\text { policies; Constitutional support; A } \\
\text { testimony; Votes }\end{array}$ & 1 & 2.70 \\
\hline
\end{tabular}

Source: The authors (2019), based on primary data. Note: The quantity and percentage refer to how many times the activity/action was used in the sample of 37 theoretical articles.

In Table 8, the sample used was the empirical articles. In this way, the activities and/or actions that the authors used in the relation of their variables were captured to test the theories and hypotheses that they were proposing. Therefore, it is possible to use such a study, in comparison with the sample of activities/actions of the theoretical articles, to arrive at conclusions, as for example, which are the most used by the authors when empirical research is desired.

Table 8. Identification in empirical articles

\begin{tabular}{|l|c|c|}
\hline \multicolumn{1}{|c|}{ ACTIVITY/ACTION } & QTY. & \% \\
\hline $\begin{array}{l}\text { Lobbying (Spending or Lobbying)/Direct } \\
\text { Corporate Lobbying (Executive)/Lobbying } \\
\text { Office in Washington }\end{array}$ & 65 & 45.45 \\
\hline $\begin{array}{l}\text { CAP (quantity, contributions, } \\
\text { existence)/Micro CPA (if practice and how } \\
\text { regular)/Macro CPA (social perspective and } \\
\text { how it should be regulated) }\end{array}$ & 54 & 37.76 \\
\hline $\begin{array}{l}\text { Contribution/Financing campaign or } \\
\text { candidate }\end{array}$ & 15 & 10.49 \\
\hline $\begin{array}{l}\text { Board Member, Directors, CEO, employee, } \\
\text { or former government official or } \\
\text { connected/Political Committee } \\
\text { Member/Political Officer/Political Party } \\
\text { Manager/Manager or official with political } \\
\text { agenda }\end{array}$ & 9 & 6.29 \\
\hline $\begin{array}{l}\text { CPA (expenses and existence of actions/ } \\
\text { activities)/Formal CPA/Informal CPA }\end{array}$ & 8 & \\
\hline
\end{tabular}




\begin{tabular}{|c|c|c|}
\hline $\begin{array}{l}\text { Activism via business council/Industrial } \\
\text { associations/National } \\
\text { associations/Payments to associated } \\
\text { entities/Corporate groups }\end{array}$ & 6 & 4.20 \\
\hline Collective action & 5 & 3.50 \\
\hline 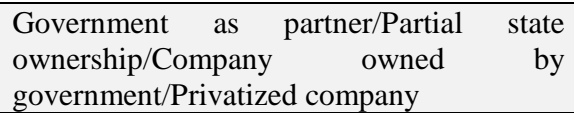 & 4 & 2.80 \\
\hline $\begin{array}{l}\text { Construction of coalitions/Coalitions of } \\
\text { interest/Coalition with competitors }\end{array}$ & 3 & 2.10 \\
\hline $\begin{array}{l}\text { Corporate Political } \\
\text { (CPS)/Information Reference Strategy }\end{array}$ & 3 & 2.10 \\
\hline $\begin{array}{l}\text { Level of a company or institutional } \\
\text { participation }\end{array}$ & 3 & 2.10 \\
\hline \begin{tabular}{lrr} 
Commercial & \multicolumn{2}{c}{ organizations/Business } \\
$\begin{array}{l}\text { Advisory } \\
\text { Associations }\end{array}$ & Group/Relevant & Business \\
\end{tabular} & 3 & 2.10 \\
\hline $\begin{array}{l}\text { Relations with policymakers/Relationship } \\
\text { with a host government }\end{array}$ & 3 & 2.10 \\
\hline $\begin{array}{l}\text { Individual action; Former civil servants on } \\
\text { the board of directors/Former government } \\
\text { official; Electoral building; Defensive } \\
\text { actions/Proactive actions; Involvement in } \\
\text { electoral politics/Executives involved; } \\
\text { Short- or long-term exchange with } \\
\text { government policymakers; Political } \\
\text { influence/Influence on government } \\
\text { regulations; } \\
\text { Expenditures/Campaign Political } \\
\begin{array}{l}\text { Advertising/Advocacy support; Receive } \\
\text { visits from government officials/Visit } \\
\text { politicians. }\end{array}\end{array}$ & 2 & 1.40 \\
\hline $\begin{array}{l}\text { Support a group of interests that occupy } \\
\text { political posts; CSR; Direct participation of } \\
\text { entrepreneurs in politics as a strategy of } \\
\text { congressmen; Corporate Communications; } \\
\text { Testimony of the congress; Contribution of } \\
\text { CEOs; Direct petition; Company pride of } \\
\text { local government; Write to elected officials } \\
\text { about public policy; Campaign for } \\
\text { candidates holding public office; } \\
\text { Government branches with veto power in } \\
\text { policy change in each country; Campaign } \\
\text { funds; Government affairs offices; Have } \\
\text { PAC; Invitation for hosting; Independent } \\
\text { expenditures with federal organizations; } \\
\text { Interaction government officials in industry } \\
\text { meetings; Market opening petitions; Media; } \\
\text { Member of the Chinese Communist Party; } \\
\text { Party chief or general secretary on the board } \\
\text { of directors; Negotiation with regulators; } \\
\text { Appointment to public agency; Technical } \\
\text { standardization (standards for anticipating } \\
\text { the demands of policymakers and shaping } \\
\text { policy); Public meetings on issues of local } \\
\text { interest; Affair with party; Permissions; } \\
\text { Political objectives; Revolving doors } \\
\text { (personnel movement); Private political } \\
\text { actions; Public welfare; Representation of } \\
\text { political interests; Strategy of social force } \\
\text { mobilization; Soft-money contribution; } \\
\text { Bribery; Subsidies; Use law firm in } \\
\text { Washington more than once every six } \\
\text { months. }\end{array}$ & 1 & 0.70 \\
\hline
\end{tabular}

Source: The authors (2019), based on primary data. Note: The quantity and percentage refer to how many times the activity/action was used in the sample of 143 empirical articles.
Table 9 presents the theories used by the authors of the studies, on a scale of two or more apparitions.

Table 9. Theories used

\begin{tabular}{|l|c|c|}
\hline \multicolumn{1}{|c|}{ Theories } & QTY. & $\%$ \\
\hline CPA & 90 & 50.00 \\
\hline Corporate Political Strategy (CPS) & 14 & 7.78 \\
\hline Lobbying & 11 & 6.11 \\
\hline Theory of resource dependency & 10 & 5.56 \\
\hline $\begin{array}{l}\text { Institutional (level, environment, change, } \\
\text { characteristic, context, field, investors, } \\
\text { property) }\end{array}$ & 8 & 4.44 \\
\hline RBV & 8 & 4.44 \\
\hline CSR & 6 & 3.33 \\
\hline Institutional theory & 6 & 3.33 \\
\hline $\begin{array}{l}\text { Finance (performance, regulation, reporting } \\
\text { quality) }\end{array}$ & 5 & 2.78 \\
\hline $\begin{array}{l}\text { Market (stocks, capacity, distortion, strategic, } \\
\text { uncertainty) }\end{array}$ & 5 & 2.78 \\
\hline Market and/or environment regulation & 5 & 2.78 \\
\hline $\begin{array}{l}\text { Political Capabilities, Nonmarket Strategy, } \\
\text { Political Strategies, and Agency Theory }\end{array}$ & 4 & 2.22 \\
\hline $\begin{array}{l}\text { Political connections, Contribution via PAC, } \\
\text { Firm performance, Political economy, } \\
\text { Collective action theory, Class cohesion } \\
\text { theory, Firm behavior theory, and Stakeholder } \\
\text { theory }\end{array}$ & 3 & 1.67 \\
\hline $\begin{array}{l}\text { Political activism, Corporate elites, Political } \\
\text { action of the firm, Corporate governance, } \\
\text { Political influence, Organizational behavior, } \\
\text { Political CSR, Business-government } \\
\text { relationship, Social Network Theory, Bribery } \\
\text { and corruption, Theory of capacities, Theory } \\
\text { of the Transaction Cost, Varieties of } \\
\text { Capitalism }\end{array}$ & 2 & \\
\hline $\begin{array}{l}\text { Soure: The authors (2019), based on primary } \\
\text { (n) }\end{array}$ & \\
\hline
\end{tabular}

Source: The authors (2019), based on primary data. Note: The quantity and percentage refer to how often the theory was used in the theoretical reference of the sample of 180 articles.

One of the highlights of this study is the analysis performed to identify the countries where the surveys of each of the sample articles were carried out, in the form of a map presented in Figure 4.

Figure 4. Geographical distribution of sample countries

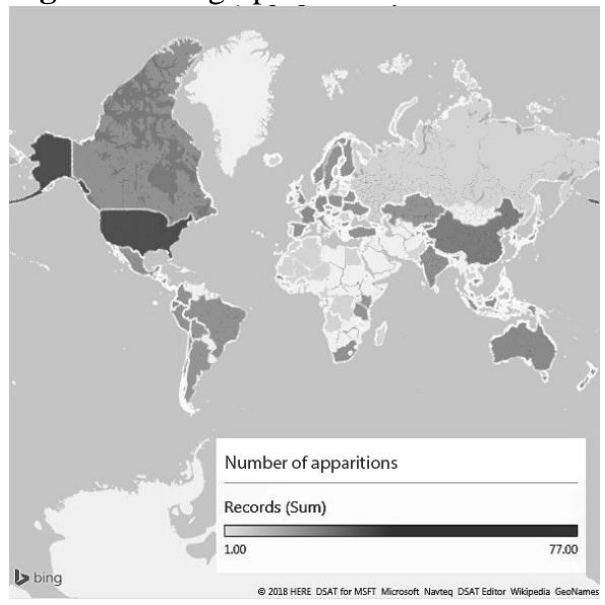

Source: The authors (2019) based on primary data. 
Table 10. Top 30 most cited works

\begin{tabular}{|c|c|c|c|c|}
\hline$\#$ & Reference & $\begin{array}{c}\text { Qty. } \\
\text { quotes }\end{array}$ & Research question & Discoveries \\
\hline 1 & $\begin{array}{l}\text { Hillman e Hitt } \\
\text { (1999) }\end{array}$ & 500 & $\begin{array}{l}\text { How do general approaches to political } \\
\text { action (transactional and relational), two } \\
\text { levels of participation (individual and } \\
\text { collective), and three types of generic } \\
\text { political strategies (information, financial } \\
\text { incentive, and constituency building) come } \\
\text { about? }\end{array}$ & $\begin{array}{l}\text { A comprehensive taxonomy of specific political strategies, } \\
\text { constructing a decision model of political strategy } \\
\text { formulation that integrates and expands the previous } \\
\text { diffused literature and explores variables that affect the } \\
\text { formulation of the political strategy }\end{array}$ \\
\hline 2 & $\begin{array}{l}\text { Hillman et al. } \\
\text { (2004) }\end{array}$ & 366 & $\begin{array}{l}\text { Review of academic work in management, } \\
\text { political science, economics and sociology in } \\
\text { the area of corporate political activity (CPA) }\end{array}$ & $\begin{array}{l}\text { The CPA continues to grow and expand. As trade becomes } \\
\text { increasingly global, goods and services move through } \\
\text { more and more political jurisdictions, which in turn bring } \\
\text { more and more political actors and institutions }\end{array}$ \\
\hline 3 & $\begin{array}{l}\text { Grier et al. } \\
(1994)\end{array}$ & 237 & $\begin{array}{l}\text { What factors determine the overall level of } \\
\text { political activity in interest groups? }\end{array}$ & $\begin{array}{l}\text { Industries with the greatest potential benefits of } \\
\text { government assistance contribute systematically more, but } \\
\text { the capacity to realize these benefits is limited by problems } \\
\text { of collective action }\end{array}$ \\
\hline 4 & $\begin{array}{l}\text { Schuler et al. } \\
(2002)\end{array}$ & 221 & $\begin{array}{l}\text { How do companies achieve competitive } \\
\text { similarity in the political process, } \\
\text { considering the incentives created by the US } \\
\text { electoral and political process? }\end{array}$ & $\begin{array}{l}\text { To gain access to policymakers, politically active } \\
\text { companies combine corporate political activities }\end{array}$ \\
\hline 5 & $\begin{array}{l}\text { Cooper et al. } \\
(2010)\end{array}$ & 144 & $\begin{array}{l}\text { Is there causal evidence of PAC's } \\
\text { contributions to future stock prices? }\end{array}$ & $\begin{array}{l}\text { The firm's support for the candidates is positively and } \\
\text { significantly correlated with the transverse assignment of } \\
\text { future returns }\end{array}$ \\
\hline 6 & $\begin{array}{l}\text { Hansen and } \\
\text { Mitchell } \\
(2000)\end{array}$ & 130 & $\begin{array}{l}\text { How do you think of PAC contributions, } \\
\text { lobbying, and charitable donations in terms } \\
\text { of corporate strategic behavior and the } \\
\text { implications of "strangeness" for different } \\
\text { business policies? }\end{array}$ & $\begin{array}{l}\text { The size of the company increases the likelihood of } \\
\text { mobilization and political activity. Foreign companies } \\
\text { adapt to local behavior but try to avoid the appearance of } \\
\text { influencing the politics of another country }\end{array}$ \\
\hline 7 & Getz (1997) & 128 & $\begin{array}{l}\text { An analysis of the literature on corporate } \\
\text { political action (CPA), integrating the } \\
\text { perspectives of nine basic theories of social } \\
\text { sciences. }\end{array}$ & $\begin{array}{l}\text { It is understood very well which companies get involved in } \\
\text { the CPA and their reasons for doing so. The nine theories } \\
\text { of social science present complementary and non- } \\
\text { contradictory images }\end{array}$ \\
\hline 8 & $\begin{array}{l}\text { Marquis and } \\
\text { Qian (2014) }\end{array}$ & 111 & $\begin{array}{l}\text { How and why do companies respond } \\
\text { strategically to government signals about the } \\
\text { corporate activity? }\end{array}$ & $\begin{array}{l}\text { Signaling is a mechanism of political influence. } \\
\text { Government dependence exposes companies to the } \\
\text { pressure of legitimacy. They face the risk of association } \\
\text { and are more likely to take CSR actions }\end{array}$ \\
\hline 9 & $\begin{array}{l}\text { Chin et al. } \\
(2013)\end{array}$ & 93 & $\begin{array}{l}\text { What is the influence on the organizational } \\
\text { results of CEO political ideology, } \\
\text { specifically with political conservatism } \\
\text { versus liberalism? }\end{array}$ & $\begin{array}{l}\text { CEOs vary in their preferences or values, and these } \\
\text { differences give rise to heterogeneous results in firms }\end{array}$ \\
\hline 10 & $\begin{array}{l}\text { Lenway and } \\
\text { Rehbein } \\
(1991)\end{array}$ & 80 & $\begin{array}{l}\text { What is the engine of corporate involvement } \\
\text { with the US International Trade } \\
\text { Commission? }\end{array}$ & $\begin{array}{l}\text { Organizational backlash is an important determinant. The } \\
\text { profitability of a company has more impact on certain } \\
\text { types of political activity. The presence of a large number } \\
\text { of politically inactive companies in one industry does not } \\
\text { prevent other companies from becoming politically active }\end{array}$ \\
\hline 11 & $\begin{array}{l}\text { Lawton et al. } \\
(2013)\end{array}$ & 76 & $\begin{array}{l}\text { An analysis of the literature on corporate } \\
\text { political activity (CPA) and the implications } \\
\text { for organizational performance }\end{array}$ & $\begin{array}{l}\text { It is necessary to use more RBV theory in the CPA to } \\
\text { understand sustainable performance. The CPA perspective } \\
\text { needs to move to the integration of theory rather than the } \\
\text { disintegration of theory }\end{array}$ \\
\hline 12 & Barley (2010) & 75 & $\begin{array}{l}\text { How did corporations build an institutional } \\
\text { field during the } 1970 \text { s and } 1980 \text { s to exert } \\
\text { more influence over the US federal } \\
\text { government? }\end{array}$ & $\begin{array}{l}\text { The unions have invented political action committees } \\
\text { (PACs). Environmental and public interest groups, as well } \\
\text { as grassroots organizations, used later through trade } \\
\text { associations, public relations firms and ad hoc } \\
\text { organizations. Citizens and labor groups formed coalitions }\end{array}$ \\
\hline 13 & $\begin{array}{l}\text { Quinn and } \\
\text { Shapiro } \\
\text { (1991) }\end{array}$ & 75 & $\begin{array}{l}\text { What forms and mechanisms of power } \\
\text { business in US politics, under time series } \\
\text { models, explain taxation and redistribution? }\end{array}$ & $\begin{array}{l}\text { The forms are political partisanship, with Democratic } \\
\text { administrations increasing the tax burden. Yet, } \\
\text { involvement in electoral funding is also influential }\end{array}$ \\
\hline 14 & $\begin{array}{l}\text { Lux et al. } \\
(2011)\end{array}$ & 74 & $\begin{array}{l}\text { What factors, and to what extent, influence } \\
\text { companies to become involved in the CPA; } \\
\text { and if this affects the performance of the } \\
\text { company, to what extent? }\end{array}$ & $\begin{array}{l}\text { Many factors are CPA engines, very few affect the CPA. } \\
\text { The CPA is positively related to the company's } \\
\text { performance and is an important determinant of its } \\
\text { performance }\end{array}$ \\
\hline 15 & $\begin{array}{l}\text { Stenzel and } \\
\text { Frenzel } \\
(2008)\end{array}$ & 68 & $\begin{array}{l}\text { How do electric companies respond } \\
\text { strategically to subsidy schemes that support } \\
\text { renewable energy technologies? }\end{array}$ & $\begin{array}{l}\text { They react where their core businesses are affected. Also, } \\
\text { they will engage in a reactive or proactive way, depending } \\
\text { on the degree to which they can benefit from future policies }\end{array}$ \\
\hline
\end{tabular}

Revista de Negócios, v. 24, n. 1, p. 7-20, January, 2019. 


\begin{tabular}{|c|c|c|c|c|}
\hline 16 & Lord (2000) & 66 & $\begin{array}{l}\text { What is the impact of corporate political } \\
\text { activities (CPA) on legislative decision- } \\
\text { making? }\end{array}$ & $\begin{array}{l}\text { All political activities have at least some degree of } \\
\text { influence in legislative decision-making. Legislators are } \\
\text { "doubled," and can have personal beliefs and preferences } \\
\text { as well as active leadership to change, approve or win } \\
\text { legislation }\end{array}$ \\
\hline 17 & Burris (1987) & 60 & $\begin{array}{l}\text { An evaluation of six popular theories of } \\
\text { political business partisanship }\end{array}$ & $\begin{array}{l}\text { There is support for the Yankee-Cowboy theory and the } \\
\text { theory of the regulatory environment. The most central or } \\
\text { dominant firms tend to be politically moderate or liberal. } \\
\text { The degree to which corporate political behavior is } \\
\text { conditioned by fiscal and regulatory relations }\end{array}$ \\
\hline 18 & $\begin{array}{l}\text { Mitchell, } \\
\text { Hansen, and } \\
\text { Jepsen (1997) }\end{array}$ & 60 & $\begin{array}{l}\text { How is the decision to form a PAC, the } \\
\text { amount to be contributed and the number of } \\
\text { candidates to be supported given? }\end{array}$ & $\begin{array}{l}\text { The profit maximization model is supported. Size of } \\
\text { contributions and the number of candidates explain more } \\
\text { than } 50 \text { percent of the variance. Sales to the government } \\
\text { are another motivation }\end{array}$ \\
\hline 19 & Burris (2001) & 59 & $\begin{array}{l}\text { What are the differences between companies } \\
\text { and individual capitalists as political actors? }\end{array}$ & $\begin{array}{l}\text { Corporations are more limited by pragmatic } \\
\text { considerations, while individual capitalists are freer to } \\
\text { follow their true political preferences in the choice of } \\
\text { candidates or parties to be supported }\end{array}$ \\
\hline 20 & $\begin{array}{l}\text { Keim and } \\
\text { Zeithaml } \\
(1986)\end{array}$ & 56 & $\begin{array}{l}\text { What is the theoretical basis for determining } \\
\text { effective corporate political strategies? }\end{array}$ & $\begin{array}{l}\text { Reducing information costs for the individual constituent } \\
\text { increases the likelihood of political action. Companies with } \\
\text { defined constituency programs have more impact on } \\
\text { legislative decisions }\end{array}$ \\
\hline 21 & $\begin{array}{l}\text { Hadani and } \\
\text { Schuler } \\
(2013)\end{array}$ & 50 & $\begin{array}{l}\text { What is the relationship between corporate } \\
\text { political activity (CPA) and financial return? }\end{array}$ & $\begin{array}{l}\text { The CPA is negatively associated with cumulative political } \\
\text { investments and accounting performance; however, it is } \\
\text { positively associated with market performance for } \\
\text { companies in regulated industries. }\end{array}$ \\
\hline 22 & $\begin{array}{l}\text { Rehbein and } \\
\text { Schuler } \\
(1999) \\
\end{array}$ & 47 & $\begin{array}{l}\text { How does an integrative model of corporate } \\
\text { political action, based on the behavioral } \\
\text { theory of the company? }\end{array}$ & $\begin{array}{l}\text { The internal characteristics of a company are a key factor, } \\
\text { with the predictive power of behavioral theory as the basis } \\
\text { for corporate political action. }\end{array}$ \\
\hline 23 & $\begin{array}{l}\text { Kroszner and } \\
\text { Stratmann } \\
(2005)\end{array}$ & 35 & $\begin{array}{l}\text { Are politicians following the reputational } \\
\text { development strategy rewarded with high } \\
\text { levels of contributions to corporate } \\
\text { campaigns? }\end{array}$ & $\begin{array}{l}\text { The level of PAC contributions increases as a legislator } \\
\text { clarifies its reputation. }\end{array}$ \\
\hline 24 & $\begin{array}{l}\text { Brasher and } \\
\text { Lowery } \\
\text { (2006) }\end{array}$ & 34 & $\begin{array}{l}\text { How do organizations engage in corporate } \\
\text { political activities? }\end{array}$ & $\begin{array}{l}\text { Large companies are much more politically active than } \\
\text { small ones. But not in terms of money spent in lobbying. } \\
\text { The economic health of companies and levels of } \\
\text { competition are not important factors. }\end{array}$ \\
\hline 25 & Jia ( & 34 & $\begin{array}{l}\text { If and when companies that are already } \\
\text { involved in collective bargaining actions are } \\
\text { more (or less) likely to pursue political } \\
\text { actions. }\end{array}$ & $\begin{array}{l}\text { Companies that are already members of a key collective } \\
\text { political association are more likely to have an interest in } \\
\text { political action. It is stronger in less economically } \\
\text { developed provinces. Weaker where regulatory burdens } \\
\text { for businesses are heavier and owners have amassed } \\
\text { political connections during a previous political career. }\end{array}$ \\
\hline 26 & $\begin{array}{l}\text { Savell et al. } \\
(2014)\end{array}$ & 31 & $\begin{array}{l}\text { Review on the efforts of the tobacco industry } \\
\text { to influence market regulations. }\end{array}$ & $\begin{array}{l}\text { The industry mainly conveys these arguments through } \\
\text { direct and indirect lobbying, promotion of voluntary codes } \\
\text { and alternative policies and the formation of alliances with } \\
\text { other industrial sectors. }\end{array}$ \\
\hline 27 & $\begin{array}{l}\text { Windsor } \\
\text { (2007) }\end{array}$ & 26 & $\begin{array}{l}\text { How are resource allocation choices } \\
\text { involved in integrating cross-border and } \\
\text { politically multinational corporations } \\
(\mathrm{MNCs}) \text { ? }\end{array}$ & $\begin{array}{l}\text { Cross-border CPA is a "horizontal" allocation of resources } \\
\text { when operating in several countries. It is a "vertical" } \\
\text { allocation of resources between subnational, national, } \\
\text { regional and global levels. The multiple political areas are } \\
\text { shaped by non-market institutions, corruption conditions } \\
\text { and stakeholder demand for corporate social responsibility. }\end{array}$ \\
\hline 28 & $\begin{array}{l}\text { Schuler } \\
\text { (1999) }\end{array}$ & 25 & $\begin{array}{l}\text { How do corporate interests determine their } \\
\text { preferences for political action? }\end{array}$ & $\begin{array}{l}\text { Understanding corporate political action must involve } \\
\text { organizational forces that affect how a company pursues, } \\
\text { processes, and acts on information regarding public policy } \\
\text { issues. }\end{array}$ \\
\hline 29 & Wilson (1990) & 25 & $\begin{array}{l}\text { How important do corporations attribute to } \\
\text { different political activities and why } \\
\text { corporations are, or not, politically active? }\end{array}$ & $\begin{array}{l}\text { Business relationships are conducted directly between } \\
\text { individual corporations and government, not collective } \\
\text { ones. They are more politically active so that they can } \\
\text { connect more to the government than to combat the } \\
\text { supposed enemies of capitalism. }\end{array}$ \\
\hline 30 & Keim (1981) & 24 & $\begin{array}{l}\text { How does the public policy process lead to } \\
\text { suggestions for making a business more } \\
\text { effective participant in decision making? }\end{array}$ & $\begin{array}{l}\text { A successful political strategy will encourage the } \\
\text { authorities to better respond to business interests and the } \\
\text { broader natural circle of business. The business will } \\
\text { motivate these people to political action only by attracting } \\
\text { their interests. }\end{array}$ \\
\hline
\end{tabular}

Source: The authors (2019), based on primary data.

Revista de Negócios, v. 24, n. 1, p. 7-20, January, 2019. 
The map was built with the aid of Excel software, based on the 180 selected articles. The work was done manually, in reading one by one, to identify the country or countries used as samples. In this illustration, you can identify which countries the CPA topic has already been explored. And the opposite also, in which countries there has not yet been data collection to test CPA theories.

The scale begins with the appearance of an article and follows up to 77 articles. As the map shows, the country where the subject is most searched in the United States of America.

Finally, a citation analysis was performed to identify the roles that had the greatest impact in the field, as assessed by the frequency of citations (Tahai \& Meyer, 1999). In this way, Table 10 presents more comprehensively the understanding of the captured researches. For this, the 30 most cited articles were included in the study sample.

In short, these are the 30 most influential articles in the CPA area. Starting from this universe, the author's authorship, the number of times they were cited, the research question elaborated by the authors for each study and the findings made in each of the 30 articles.

\section{Brazilian Research}

From the point of view of Brazilian research, through bibliometric analysis and using the filters applied in this study, no publications of Brazilian authors related to CPA were found. Thus, a survey was made, through the research of Brazilian publications on CPA and the following characteristics were obtained: they were published in the Brazilian Administration Review (BAR), Revista de Administração Contemporânea (RAC), Revista de Administração de Empresas (RAE), RaUSP Management Journal e Revista Brasileira de Gestão de Negócios (RBGN).

The publications address, among other issues, how the formal and informal mechanisms of political strategy affect the relations of multinational companies and the government in Brazil (Bachuzi et al., 2013) and suggest a model for the process of formulating and executing political strategies using as base the ethanol sector (Silva et al., 2014). The study of Camilo et al. (2012) proposes that companies connected with the political environment tend to have a positive effect on profitability and make use of the connection in periods of greater uncertainty.
There are also studies that address the political connection and business groups. Costa et al. (2013) approach to the increased diversification of business groups, and Gama et al. (2018) suggest that there is a need for historical antecedents of the business groups added to the political connection so that there is an effect on the growth of the groups.

There are still a number of theses and dissertations that address the theme of political connections in Brazil. For example, Lana (2017) discusses how political connections increase the speed of government decisions on anti-dumping practices. Caldeira (2016) addresses the political capacities of the subsidiaries of multinationals operating in Brazil, while Simioni (2018) addresses issues of lobbying in times of uncertainty in the country.

There are still other study groups on the subject at the following universities: University of Brasília (UNB), University of São Paulo (USP), Federal University of Minas Gerais (UFMG) and Federal University of Rio de Janeiro (UFRJ). For example, the article of Macedo et al., (2015) addresses the political connection and investment decisions in the capital market. The study of Astorino (2015) shows the consequences of the political connections regarding their performance and access to credit granted by BNDES. Last, but not least, the study of Dias et al. (2017) analyzes the political connections during the electoral cycle of 2010-2014.

\section{Conclusion and Future Studies}

This article aimed to highlight the importance of research on corporate political action and corporate political activity in the world and the need to develop further studies on the subject in Brazil.

Through this bibliometric analysis, it was possible to verify that in Brazil there are few studies on the subject and these are restricted to a small number of researchers. On the other hand, in the United States, Canada, China and European countries there is an advance of the articles on the subject, since the political activities in the companies have been increasingly present and their impact on the profitability (Cooper et al., 2010; Hadani \& Schuler, 2013; Hillman et al., 1999)

Because it is a subject that influences corporate profitability and impacts governments at

Revista de Negócios, v. 24, n. 1, p. 7-20, January, 2019. 
all levels - municipal, state and federal - research on corporate political action and corporate political activity can still be explored in the following aspects:

With regard to corporate political activities in the MNEs: (a) the comparison between the political activities of the MNEs in their country of origin and the MNEs in the destination country. What are the main capacities and resources needed for MNEs in the destination country to be able to influence local public policies? (Bachuzi et al., 2012; Caldeira, 2016; Cuervo-Cazurra \& Genc, 2011; Hillman \& Wan, 2005); (b) the impact on the end of the donations to electoral campaigns by companies in Brazil and the comparison with the same measure in other countries.

Regarding lobby/advocacy and lobbyists: (c) the role of government relations professionals or investor relations; the lobbyists (Caldeira, 2016; Simioni, 2018). There is also a preconception about the professionals of governmental relations in Brazil, perhaps for lack of information. In this sense, it is necessary to deepen the studies on the role of these professionals in the companies and how they work. It also becomes necessary to separate the role of government relations or lobbyist from the past, with the lobbyists of a new generation of professionals who are working in companies (Caldeira, 2016; Simioni, 2018).

Regarding the advocacy mechanism: (d) it would be interesting to deepen the research on the influence of social media as a mechanism of corporate political activity to pressure the government.

There are also issues such as: (e) the robotization of government relations consultancies, investigating the extent to which this will make the use of corporate political activities more precise, and more efficient the lawsuits with the government; (f) a fifth interesting study is the political strategy in the three spheres of government. The Brazilian studies use, for the most part, the federal sphere (Camilo et al., 2012; Costa et al., 2013; Lana, 2017), however, it is known that there is corporate political activity in municipalities and states. In this sense, what is the impact of corporate political activities in each of the areas?

Lastly, (g) it is suggested to develop a ranking with the main corporate political activities and what conditions are sufficient and/or necessary to have an impact on the profitability of the company.
Finally, during the reading of the selected articles, new nomenclatures were identified, adopted by the authors and by the authors' action in adopting other theories related to the corporate political involvement. Such terms can serve as a starting point for a new literature review since they were not addressed in this research. Are they: corporate political advertising, corporate political analysis, corporate political connectedness, corporate political groupings, corporate political objectives, corporate political nexus, corporate political spending, corporate political unit and, business political activity.

\section{References}

Astorino, P. S. (2015). Consequências das conexões políticas para as empresas de capital aberto no Brasil: desempenho $e$ acesso a crédito do BNDES. Dissertação de Mestrado - Universidade do Estado de São Paulo (USP). https://doi.org/10.11606/D.12.2015.tde11112015-134451

Bachuzi, K. R., Zacharias, S. A., Broering, L. W., Bandeira-de-Mello, R., \& Areola, M. F. (2012). The Role of Home Country Political Resources for Brazilian Multinationals Companies. In AIB Annual Meeting. Washington.

Bachuzi, K. R., Zacharias, S. A., Broering, L. W., Bandeira-de-Mello, R., \& Areola, M. F. (2013). The Role of Home Country Political Resources for Brazilian Multinationals Companies. BAR - Brazilian Administration Review, 10(4).

Barley, S. R. (2010). Building an institutional field to corral a government: A case to set an agenda for organization studies. Organization Studies, 31(6), 777-805. https://doi.org/10.1177/0170840610372572

Boddewyn, J. J. (2007). The Internationalization of the Public-Affairs Function in U.S. Multinational Enterprises. Business \& Society, 46(2), 136-173.

Botelho, L. L. R., Cunha, C. C. A., \& Macedo, M. (2011). O Método da Revisão Integrativa nos Estudos Organizacionais. Gestão e Sociedade, $5(11)$, 121-136. https://doi.org/10.1017/CBO9781107415324. 004

Brasher, H., \& Lowery, D. (2006). The Corporate 
Context of Lobbying Activity. Business and Politics, 8(01), 1-23. https://doi.org/10.2202/1469-3569.1124

Buchholz, R. A. (1988). Public policy issues for management. Englewood Cliffs, NJ: PrenticeHall.

Burris, V. (1987). The Political Partisanship of American Business: A Study of Corporate Political Action Committees. American Sociological Review, 52(6), 732-744.

Burris, V. (2001). The Two Faces of Capital: Corporations and Individual Capitalists as Political Actors. American Sociological Review, 66(3), 361-381.

Caldeira, C. A. (2016). Configuração das Capacidades Políticas das Subsidiárias de Multinacionais Operando no Brasil. Dissertação de Mestrado, Fundação Getulio Vargas, São Paulo, SP, Brasil.

Camilo, S. P. O., Marcon, R., \& Bandeira-deMello, R. (2012). Conexões Políticas e Desempenho : um Estudo das Firmas Listadas na BM\&F Bovespa. Revista de Administração ..., 784-805.

Chin, M. K., Hambrick, D. C., \& Treviño, L. K. (2013). Political Ideologies of CEOs: The Influence of Executives' Values on Corporate Social Responsibility. Administrative Science Quarterly, 58(2), 197-232. https://doi.org/10.1177/0001839213486984

Cooper, M. J., Gulen, H., \& Ovtchinnikov, A. V. (2010). Corporate political contributions and stock returns Main question. Journal of Finance, 65(2), 687-724. https://doi.org/10.1111/j.15406261.2009.01548.x

Costa, M. W. O., Bandeira-de-Mello, R., \& Marcon, R. (2013). A influência da conexão política na diversificação dos grupos empresariais brasileiros. Revista de Administração de Empresas, 53(4), 376-387.

Cuervo-Cazurra, A., \& Genc, M. (2011). How context matters: Non-market advantages of developing-country MNEs. Journal of Management Studies, 48(2).

Dias, B. W. ., Mendes, D. ., \& Macedo, M. A. S. (2017). Estrutura de Capital e Conexões Políticas: Uma Análise durante o Ciclo Político Nacional de 2010 a 2014. São Paulo.

Dorobantu, S., Kaul, A., \& Zelner, B. (2017). Nonmarket Strategy Reserach Through the Lens of New Institutional Economics: An
Integrative Review and Future Directions. Strategic Management Journal, 38(1), 114140. https://doi.org/10.1002/smj

Gama, M. A. B., Bandeira-de-mello, R., \& Spuldaro, J. D. (2018). Political strategy and the growth of business groups. RAUSP Management Journal, 53, 35-48. https://doi.org/10.1016/j.rauspm.2017.06.001

Getz, K. A. (1997). Research in Corporate Political Action. Business \& Society, 36(1), 32-72. https://doi.org/0803973233

Grier, K. B., Munger, M. C., Carolina, N., Hill, C., \& Roberts, B. E. (1994). The Determinants of Industry Political Activity , 1978-1986. The American Political Science Review, 88(4), 911-926.

Gundlach, G. T., Root, A. R., \& Murphy, P. E. (1992). Corporate political action: The erosion of the political speech doctrine. Journal of Business Research, 24(4), 331$346 . \quad$ https://doi.org/10.1016/01482963(92)90038-D

Hadani, M., \& Schuler, D. A. (2013). In Search of El Dorado: The Elusive Financial Returns on Corporate Political Investments. Strategic Management Journal, 34, 165-181. https://doi.org/10.1002/smj.2006

Hansen, W. L., \& Mitchell, N. J. (2000). Disaggregating and Explaining Corporate Political Activity: Domestic and Foreign Corporations in National Politics. The American Political Science Review, 94(4), 891-903.

Hart, C. (1998). Doing A Literature Review: Releasing the Social Science Research Imagination. London: SAGE.

Hillman, A. J., \& Hitt, M. A. (1999). Corporate Political Strategy Formulation: A Model of Approach, Participation, and Strategy Decisions. The Academy of Management Review, 24(4), 825. https://doi.org/10.2307/259357

Hillman, A. J., Keim, G. D., \& Schuler, D. (2004). Corporate political activity: A review and research agenda. Journal of Management, 30(6), 837-857. https://doi.org/10.1016/j.jm.2004.06.003

Hillman, A. J., Zardkoohi, A., \& Bierman, L. (1999). Corporate political strategies and firm performance: Indications of firm-spe ... Management, 20(1), 67. https://doi.org/10.1002/smj.2495 
Hillman, A., \& Wan, W. P. (2005). The determinants of MNE subsidiaries' political strategies: evidence of institutional duality. Journal of International Business Studies, 36.

Jia, N. (2014). Are collective political actions and private political actions substitutes or complements? Empirical evidence from china's private sector. Strategic Management Journal, $\quad 35, \quad 292-315$. https://doi.org/10.1002/smj

Keim, G. D. (1981). Foundations of a Political Strategy for Business. California Management Review, 23(3), 41-48. https://doi.org/10.2307/41172600

Keim, G. D., \& Zeithaml, C. P. (1986). Corporate Political Strategy and Legislative Decision Making: A Review and Contingency Approach. The Academy of Management Review, 11(4), 828-843.

Kroszner, R. S., \& Stratmann, T. (2005). Corporate Campaign Contributions, Repeat Giving, and the Rewards to Legislator Reputation. The Journal of Law \& Economics, 48(1), 41-71.

Lana, J. (2017). Time is money: O efeito temporal das estratégias políticas corporativas. Tese de Doutorado, Fundação Getulio Vargas, São Paulo, SP, Brasil.

Lawton, T., Mcguire, S., \& Rajwani, T. (2013). Corporate Political Activity: A Literature Review and Research Agenda. International Journal of Management Reviews, 15(1), 86$105 . \quad$ https://doi.org/10.1111/j.14682370.2012.00337.x

Lenway, S. A., \& Rehbein, K. (1991). Leaders , Followers, and Free Riders: An Empirical Test of Variation in Corporate Political Involvement. The Academy of Management Journal, 34(4), 893-905.

Lord, M. D. (2000). Corporate Political Strategy and Legislative Decision Making. Business \& Society, 39(1), 76-93. https://doi.org/10.1177/00076503000390010 6

Lux, S., Crook, T. R., \& Woehr, D. J. (2011). Mixing business with politics: A metaanalysis of the antecedents and outcomes of corporate political activity. Journal of Management, $\quad 37(1), \quad$ 223-247. https://doi.org/10.1177/0149206310392233

Macedo, M. A. J., Augusto, C., \& Machado, M. (2015). Conexões políticas e as empresas brasileiras: Um estudo experimental sobre as decisões de investimento no mercado de capitais. Advances in Scientific and Applied Accounting, 8(2), 157-178.

Mack, C. (1997). Business, politics, and the practice of government relations. Westport, CT: Quorum Brooks.

Marquis, C., \& Qian, C. (2014). Corporate Social Responsibility Reporting in China: Symbol or Substance? Organization Science, 25(1), 127148. https://doi.org/10.1287/orsc.2013.0837

Mitchell, N. J., Hansen, W. L., \& Jepsen, E. M. (1997). The Determinants of Domestic and Foreign Corporate Political Activity. The Journal of Politics, 59(4), 1096-1113.

Mulkern, J. R., Handler, E., \& Godtfredsen, L. (1981). Corporate PAC s as Fundraisers. California Management Review, 23(3), 4955. https://doi.org/10.2307/41172601

Porter, M. E., \& Kramer, M. R. (2006). Strategy and Society: The Link between Competitive Advantage and Corporate Social Responsibility. Harvard Business Review, 84(12), 78-92.

Quinn, D. P., \& Shapiro, R. Y. (1991). Business Political Power: The Case of Taxation. The American Political Science Review, 85(3), 851-874.

Rehbein, K. A., \& Schuler, D. A. (1999). Testing the firm as a filter of corporate political action. Business and Society, 38(2), 144-166. https://doi.org/10.1177/00076503990380020 2

Savell, E., Gilmore, A. B., \& Fooks, G. (2014). How Does the Tobacco Industry Attempt to Influence Marketing Regulations? A Systematic Review. PLoS ONE, 9(2), e87389. https://doi.org/10.1371/journal.pone.0087389

Schuler, D. A. (1999). Corporate Political Action: Rethinking the Economic and Organizational Influences. Business and Politics, 1(1), 8398. https://doi.org/10.1515/bap.1999.1.1.83

Schuler, D. A., Rehbein, K., \& Cramer, R. D. (2002). Pursuing Strategic Advantage through Political Means: A Multivariate Approach. The Academy of Management Journal, 45(4), 659-672.

Shaffer, B. (1995). Firm-Level Responses To Government-Regulation - Theoretical and Research Approaches. Journal of Management, 21(3), 495-514. https://doi.org/10.1016/0149-2063(95)900179 
Silva, A. T. B., Caldeira, C. A., \& Bandeira-deMello, R. (2014). Dinâmica da Formulação e Execução de Estratégias Políticas no Setor de Etanol. Revista de Administração ContemporâNea, 8(2), 22-40.

Simioni, A. Z. (2018). Estratégia de informação: Lobby em ambientes de mudanças políticas. Dissertação de Mestrado, Fundação Getulio Vargas, São Paulo, SP, Brasil.

Stenzel, T., \& Frenzel, A. (2008). Regulating technological change-The strategic reactions of utility companies towards subsidy policies in the German, Spanish and UK electricity markets. Energy Policy, 36(7), 2645-2657. https://doi.org/10.1016/j.enpol.2008.03.007

Suarez, S. L. (2000). Does Business Learn?: Tax Breaks, Uncertainty, and Political Strategies. University of Michigan Press.

Tahai, A., \& Meyer, M. J. (1999). A revealed preference study of management journals' direct influences. Stratrategic Management Journal, 20, 279-296. https://doi.org/10.1002/(SICI)10970266(199903)20:3<279::AIDSMJ33>3.0.CO;2-2

Wilson, G. K. (1990). Corporate Political Strategies. British Journal of Political Science, 20(2), 281-288.

Windsor, D. (2007). Toward a global theory of cross-border and multilevel corporate political activity. Business and Society, 46(2), 253278.

https://doi.org/10.1177/0007650307301387

Zupic, I., \& Cater, T. (2015). Bibliometric Methods in Management and Organization. Organizational Research Methods, 18(3), 429-472.

https://doi.org/10.1177/1094428114562629 